\title{
Conference on Advanced Computation Techniques
}

During the recent war there was tremendous development of certain types of computing devices. The big Harvard-IBM marhine indicates the way in which a whole battery of IBM equipment can be brought under automatic electric control. Electronic devices have ber $n$ constructed, or are under development, which promise astronomical speeds for numerical processes. At the Bell Laboratories there has been important development of automatic relay computing. Thus, with war's end these and other similar developments suggest that there will soon be available mechanical and electrical computing equipment which, in terms of speed and flexibility, will completely outdistance anything thought of before.

With this in mind the desirability of a Conference of those who, in this country and in England, have been recently directly and indirectly connected with the output of large computing machines became evident, and the National Research Council Committee on Mathematical Tables and Other Aids to Computation took steps for its organization. Most of the responsibility of this organization was placed in the hands of the Committee's Subcommittee Z (On Calculating Machines and Mechanical Computation) which then ${ }^{1}$ had the following membership:
L. J. Comrie, Chairman
S. H. Caldwell, Vice-Chairman
J. C. P. Miller
H. H. AIKEN
G. R. STIBITZ
D. H. LEHMER
I. A. Travis
J. R. WOMERSLEY.

Since the chairman had not t $_{i}$ yet arrived in this country, the vice-chairman carried out most of the detailed arrangements.

The Massachusetts Institute of Technology not only offered its facilities for such a gathering but also suggested that it should coincide with the first public demonstration of its new Differential Analyzer. The dates for the gathering were fixed as October $29,30,31,1945$. There were the following 84 guests who accepted our invitation:

Abramowitz, Milton............Math. Tables Project, 150 Nassau St., New York City Aiken, H. H. (Commander)....... Computation Project, Cruft Laboratory, Harvard University

Alt, Franz (L.t.). . . . . . . . . . Ballistic Research Laboratory, Aberdeen Proving Ground, Maryland

Archibald, R. C. (Prof.) ......... Nat. Res. Council Comm. (Brown University)

Arnold, H. A. (Lt. Commander). . . Computation Project, Cruft Laboratory

Bennot, Maude (Miss).........25 Ridgeway Avenue, Needham, Mass.

Bergman, Stefan (Dr.). . . . . . . . Brown University

Berkeley, E. C. (Lt.) . . . . . . . Computation Project, Cruft Laboratory

Block, R. M............... Computation Project, Cruft Laboratory

Bode, H. W. (Dr.) ............. Bell Telephone Laboratories, New York City

Brainerd, J. G. (Prof.) . . . . . . . . University of Pennsylvania

Brendle, Ruth (Miss) . ......... Computation Project, Cruft Laboratory 
Name Representing

Bryant, R. C. (Lt. ) . . . . . . . . . Office of Research \& Inventions, 1 Park Avenue, New York City

Bush, Vannevar (Dr.).......... Carnegie Institution, Washington, D. C.

Caldwell, S. H. (Prof.) . . . . . . . Nat. Res. Council Comm. (Mass. Inst. of Technology)

Campbell, R. V. D. (Ensign)....... Computation Project, Cruft Laboratory

Carter, G. K. . . . . . . . . . . . . . General Electric Co., Schenectady, N. Y.

Colbath, D. L................ General Electric Co.

Comrie, L. J. (Dr.) . . . . . . . . . Nat. Res. Council Comm. (London, England)

Concordia, Charles............ General Electric Co.

Crawford, P. O. jr............. Office of Research \& Inventions

Cunningham, L. E. (Dr.) . . . . . . Ballistic Research Laboratory

Curry, H. B. (Dr.)............. Ballistic Research Laboratory

Dederick, L. S. (Dr.)............ Ballistic Research Laboratory

Desch, J. R. . . . . . . . . . . . National Cash Register Co., Dayton, Ohio

Douglas, E. M............. International Business Machines Corp., 590 Madison Ave., New York City

Dwight, H. B. (Prof.) . . . . . . . . Mass. Inst. of Technology

Eckert, J. P. jr. . . . . . . . . . . University of Pennsylvania

Forrester, J. W. . . . . . . . . . . . Mass. Inst. of Technology

Goldstine, H. H. (Capt.)......... Ballistic Research Laboratory

Gore, O. L. (Lt.) . . . . . . . . . Office of Research \& Inventions

Hamilton, F. E............. International Business Machines Corp.

Haskins, Robert (Lt.) . . . . . . . Office of Research \& Inventions

Hazen, H. L. (Prof.) . . . . . . . . Mass. Inst. of Technology

Henry, W. E. . . . . . . . . . . . . Mass. Inst. of Technology

Hopper, Grace (Lt.). . . . . . . . Computation Project, Cruft Laboratory

Hrones, J. A. (Prof.) . . . . . . . . . Mass. Inst. of Technology

Jordan, W. B................ General Electric Co.

Kelly, T. S. (Prof.) . . . . . . . . . . Institute Math. Statistics (Harvard University)

Kopal, Zdenek (Dr.) . . . . . . . Mass. Inst. of Technology

Kuehni, H. P................ General Electric Company

Lehmer, D. H. (Prof.). . . . . . . . Nat. Res. Council Comm. (Ballistic Research Laboratory)

Löf, J. L. C. . . . . . . . . . Mass. Inst. of Technology

Lowan, A. N. (Dr.) . . . . . . . . Math. Tables Project

Macleish, K. G. . . . . . . . . . . Eastman Kodak Co., Rochester, N. Y.

McPherson, J. C.... . . . . . . . International Business Machines Corp.

Maginniss, F. J. . . . . . . . . . . General Electric Co.

Mauchly, J. W. (Prof.) . ........ University of Pennsylvania

Mayall, Margaret (Mrs.) . . . . . . Harvard Observatory, Harvard University

Mork, R. G. . . . . . . . . . . . Office of Research \& Inventions

Mumma, R. E................ National Cash Register Co.

Myers, J. E. (Ensign) . . . . . . . . Naval Research Laboratory, Anacostia, Md.

von Neumann, John (Prof.)....... Institute Math. Statistics (Institute for Advanced Study)

Nyquist, Harry (Dr.) . . . . . . . Bell Telephone Laboratories

O'Neal, R. D. . . . . . . . . . . . Eastman Kodak Company, Rochester, N. Y.

Peterson, H. A................ General Electric Co.

Philbrick, G. A. . . . . . . . . . Foxboro Instrument Company, Foxboro, Mass.

Pitts, W. H. . . . . . . . . . . . . Mass. Inst. of Technology

Rankin, A. W. . . . . . . . . . . . . General Electric Co.

Rees, Mina S. (Dr.)........... Applied Mathematics Panel (350 Fifth Avenue, New York City)

Roosevelt, C. V. S. (Lt.) ........ Office of Research \& Inventions 
Vame Representing

Sandomire, Marion M. (Mrs.). . . Bureau of Ships, Washıngton, D. C.

Sarahan, B. L. (Lt.)............. Naval Research Labortatory

Schultz, O. T. . . . . . . . . . . . Bell Telephone Laboratories

Shannon, C. E. (Dr.)... . . . . . . . Bell Telephone Laboratories

Sternberg, Sidney (Lt.) . . . . . . . Office of Research \& Inventions

Stibitz, G. R. (Dr.) . . . . . . . . . University of Vermont, Burlington, $V^{\prime}$.

Svihel, B. T. . . . . . . . . . . Mass. Inst. of Technology

Taylor, Richard (Prof.)..........Mass. Inst. of Technology

Thomas, G. B. jr. (Prof.)........ Mass. Inst. of Technology

Tiffany, O. L. . . . . . . . . . University of Michigan

Tukey, J. W. (Prof.) . . . . . . . . Princeton University

Tyler, A. W... . . . . . . . . . . Eastman Kodak Co., Rochester, N. Y.

Verzuh, F. M.............. Mass. Inst. of Technology

Wakelin, J. W. jr. (Lt.)......... Office of Research \& Inventions

Wallman, Henry (Dr.) . . . . . . . Mass. Inst. of Technology

Warren, S. R. jr. (Prof.). . . . . . . University of Pennsylvania

Watson, F. G. (Lt. Commander).... Hydrographic Office, Navy Dept., Washington, D. C.

Wicklund, H. P. (Lt.) . . . . . . . . Office of Research \& Inventions

Wiener, Norbert (Prof.). . . . . . . Mass. Inst. of Technology

Williams, H. M. ............. National Cash Register Co.

Williams, S. B. . . . . . . . . . . Bell Telephone Laboratories

Wood, H. A. (Dr.) . . . . . . . Chance-Vought Aircraft Div. of the United Aircraft Corp., Stamford, Conn.

Wundheiler, A. W. (Dr.)......... Bureau of Ordnance

Most of these delegates arrived on October 29 and attended demonstrations of the working of the new Differential Analyzer, of which there is a detailed illustrated description by VANNEvar BuSH and S. H. CALDwell, in Franklin Institute, $J$., v. 240, Oct. 1945, p. 255-326. Our frontispiece reproduces a photograph taken at the opening session of the Differential Analyzer demonstration. Grouped about the Main Control Panel are (3) Mr. Hazen, head of the Department of Electrical Engineering at M.I.T., ( 2 \& 4) Messrs. Bush \& Caldwell, who were initially responsible for developing the Analyzer, and (1) Mr. Phillips, head of the Department of Mathematics at M.I.T. In the evening the Institute invited the Delegates to a delightful dinner at the Engineers Club on Commonwealth Ave. The addresses of JAMES R. KILlian, JR., executive vice-president of the Institute, presiding officer, GEORGE R. HARRISON, dean of science at the Institute, Leslie J. Comrie, chairman of Section Z, and Vannevar Bush, director of the Carnegie Institution of Washington, were uniformly of exceptionally happy content.

The Program carried out on Tuesday, Wednesday, October 30, 31, with L. J. Comrie and S. H. Caldwell presiding, was as follows:

Tuesday Morning, M.I.T.

Address of Welcome to the Institute by President K. T. Compton.

Introductory Remarks by VANNEVAR BusH.

"Some Industrial Applications of Machine Computing Methods" by F. J. Maginniss.

"Numerical Computation by the Use of Telephone Relays" by S. B. Williams.

Tuesday Afternoon, M.I.T.

"Some Principles of Electronic High Speed Computing" by J. G. Brainerd and J. P. Eckert, JR.

"A General Summary and a Look at the Future" by J. von NEumanN. 
Tuesday Liening, Cruft Laboratory, Harvard University

"The Automatic Sequence Calculator"'3 by H. H. AIKEN, and members of his staff.

Wednesday Morning, M.I.T.

"Simulative Techniques as an Aid to Analysis" by G. A. Philbrick.

"Application of Punched-Card Methods to Scientific Computation" by W. J. EckerT, presented by J. C. McPherson.

"The M.I.T. Center-of-Analysis Research Program" by S. H. Caldwell.

Wednesday Afternoon, M.I.T.

"The Scientific Application of Commercial Calculating Machines" by L. J. Comrie.

The Conference was most notably successful, and one heard on every side expressions of the hope that such a Conference might become an annual event.

The Committee on Mathematical Tables and Other Aids to Computation is indeed greatly indebted to officers of the administration and members of the staff of the Massachusetts Institute of Technology who did everything in their pow'er to provide a setting for securing fruitful results from such an assembly of experts.

R. C. A.

${ }^{1}$ Beginning with Nov. 1, 1945, S. H. C. became chairman, and L. J. C. vice-chairman. ${ }^{2}$ See MAC 19.

3 For illustrated notes on this Calculator see MAC 20.

\section{RECENT MATHEMATICAL TABLES}

275[A, E, F].-Peder PedFrson, (a) Über die numerische Berechnung der Kettenbrüche nebst einer Berechnung der Grundzahl der natürlichen Logarithmen, 36 p., 1940; (b) Berechnung der Grundzahl e der natürlichen Logarithmen mit 606 Dezimalen, 17 p., 1942; (c) Fortsetzung der Berechnung der Grundzahl e der natürlichen Logarithmen bis zur 808. Dezimalstelle, 21 p., 1944. Denmark, Geodætisk Institut, Meddelelse, nos. 14, 16 , and 17 respectively. $14.3 \times 22 \mathrm{~cm}$.

These three papers are accounts of the author's calculations of the fundamental constant $e$. Values of $e$ are given to $404 \mathrm{D}$ in (a), to 606D in (b) and to 808D in (c). The method of calculation was based on the continued fraction

$$
\frac{e-1}{2}=\frac{1}{1}+\frac{1}{6}+\frac{1}{10}+\frac{1}{14}+\cdots
$$

which is due to EULER, 1 but is applicable to any regular continued fraction. The general idea is set forth in (a) and may be roughly described as follows. Let $x$ be the exact value of a continued fraction and let $x_{n}$ be a given approximation to $x$ which is correct to $n$ decimals. Let also $A_{k} / B_{k}$ be any convergent of the continued fraction in which $k$ is large enough so that the value of this convergent would give $x$ to more than $n$ decimals. This means that, roughly speaking, $B_{k}$ has about $n / 2$ digits. Then $x_{k} B_{k}$ will be a decimal whose first $n / 2$ significant figures are the digits of $A_{k}$ and whose next $n / 2$ digits are zeros. Therefore if we compute denominators $B_{k}$ only, and compute only the digits of the product $x_{k} B_{k}$ which lie near the $n$th significant figure, the appearance of zeros (or nines) at this place serves as a check on the digits of $x_{n}$. Moreover, the method may be used to extend the value of $x$ beyond the $n$th decimal place by simply filling in those digits which will produce more zeros until the accuracy implicit in a particular $B_{k}$ is exceeded.

The author started with SHANKs' $137 \mathrm{D}$ value of $e$ verified by GlaISHER, ${ }^{2}$ and went on to check the value of Shanks ${ }^{3}$ (205D, last 18 wrong) and of Boorman ${ }^{4}$ (346D, last 123 wrong). The 223 correct decimals of Boorman was then the basis of an extension to 